\title{
Variation among Highbush Blueberry Cultivars for Frost Tolerance of Open Flowers
}

\author{
Lisa J. Rowland ${ }^{\mathbf{1}}$ and Elizabeth L. Ogden \\ U.S. Department of Agriculture, Agricultural Research Service, Henry A. \\ Wallace Beltsville Agricultural Research Center, Genetic Improvement of \\ Fruits and Vegetables Laboratory, Building 010A, BARC-West, 10300 \\ Baltimore Avenue, Beltsville, MD 20705
}

Fumiomi Takeda and David Michael Glenn

U.S. Department of Agriculture, Agricultural Research Service, Appalachian Fruit Research Station, 2217 Wiltshire Road, Kearneysville, WV 25430

\section{Mark K. Ehlenfeldt}

U.S. Department of Agriculture, Agricultural Research Service, Genetic Improvement of Fruits and Vegetables Laboratory, at Marucci Center for Blueberry and Cranberry Research and Extension, 125A Lake Oswego Road, Chatsworth, NJ 08019

\section{Bryan T. Vinyard}

U.S. Department of Agriculture, Agricultural Research Service, Henry A. Wallace Beltsville Agricultural Research Center, Biometrical Consulting Service, Building 005, BARC-West, 10300 Baltimore Avenue, Beltsville, MD 20705

Additional index words. bud development, cold hardiness, freezing injury, freezing tolerance, Vaccinium corymbosum

\begin{abstract}
Injury of open flowers often occurs in fruit crops by late winter or early spring frosts and can result in significant reduction in yield. In this study, freezing tolerance of open flowers of five highbush blueberry cultivars, Bluecrop, Elliott, Hannah's Choice, Murphy, and Weymouth, was determined using two freezing methods. Methods involved either placing whole plants in a radiation frost chamber or detached shoots in a glycolfreezing bath. In both methods, plants (or excised shoots) with opening flowers were exposed to temperatures ranging from -2 to $-10{ }^{\circ} \mathrm{C}$. After freeze treatments, several flower parts were evaluated for damage and the lethal temperature ${ }_{50}\left(\mathrm{LT}_{50}\right)$ determined. In order, from the most sensitive flower part to the least sensitive on average, were the corolla, filament, anther, style, exterior ovary, stigma, ovules, interior ovary, and placenta. A two-way analysis of variance (ANOVA) found no significant effect of the freezing method on the calculated freeze damage to most of the various flower parts. However, a significant genotype effect was found on freeze damage to the style, filament, anthers, and exterior ovary. Overall, 'Bluecrop' was the most sensitive to freezing, whereas 'Hannah's Choice' and 'Murphy' were the most freezing-tolerant. In conclusion, genotypic variability in frost tolerance of open highbush blueberry flowers was detected, which can be exploited in breeding for more frost-tolerant cultivars.
\end{abstract}

Like many fruit crops in the United States, blueberry (Vaccinium spp.) yields can be significantly reduced by late winter or early spring frost damage to open flowers across much of their range. These damaging frosts are expected to be on the rise as a result of global climate change and higher than average winter temperatures (Gu et al., 2008). The chilling requirements of most blueberry cultivars are satisfied by midwinter.

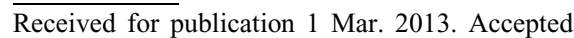
for publication 3 Apr. 2013.

${ }^{1}$ To whom reprint requests should be addressed; e-mail jeannine.rowland@ars.usda.gov. of closed flower buds and flower buds in the early stages of deacclimation. In general, midwinter hardiness of flower buds of northern highbush range in tolerance from -20 to $-30{ }^{\circ} \mathrm{C}$. Significant variation among genotypes has been noted for both midwinter hardiness and timing of deacclimation (Arora et al., 2004; Bittenbender and Howell, 1976; Ehlenfeldt et al., 2007, 2012; Rowland et al., 2005, 2008).

Only a few studies have been carried out on frost tolerance of open flowers of blueberry, primarily on the southern rabbiteye species, $V$. virgatum Aiton (syn. V. ashei Reade) (Gupton, 1983; NeSmith et al., 1999; Spiers, 1978). Spiers (1978) showed that frost tolerance of floral buds is inversely related to the stage of bud development. As flower development increases, buds and flowers become less tolerant to freezing damage. Hancock et al. (1987) reported an association between stage of bud development and susceptibility to frost damage for highbush blueberry as well. Gupton (1983) evaluated five rabbiteye cultivars for frost tolerance of open flowers and found 'Southland' to be significantly more frost-tolerant than flowers of the other four cultivars examined ('Delite', 'Woodard', 'Climax', and 'Tifblue'). NeSmith et al. (1999) examined flower damage of rabbiteye blueberry as well as fruit set after subfreezing temperature exposure. Of three flower parts evaluated, corollas were the most sensitive to freezing, followed by styles and then ovaries. Fruit set resulting from bee pollination declined after exposure to temperatures as high as $-1{ }^{\circ} \mathrm{C}$ for $1 \mathrm{~h}$ in some cultivars. However, appropriately timed gibberellin $\left(\mathrm{GA}_{3}\right)$ application, before or after freeze treatments, resulted in little reduction in fruit set with exposure to temperatures as low as -3 to $-4{ }^{\circ} \mathrm{C}$. Gibberellins applied after decapitation of styles have been shown to induce parthenocarpic fruit set in apple (Modlibowska, 1975). Thus, in blueberry, it is thought that if temperatures do not drop low enough to damage ovaries, $\mathrm{GA}_{3}$ application before or after a freeze can result in less fruit loss by stimulating parthenocarpic fruit set (NeSmith et al., 1999).

Here, we have investigated whether there is genotypic variation in frost tolerance of open highbush blueberry flowers that could be exploited in breeding highbush cultivars that are more tolerant to late winter/early spring frosts. Frost tolerance of open flowers of five highbush cultivars, Bluecrop, Elliott, Hannah's Choice, Murphy, and Weymouth, was determined using two different freezing methods. Comparisons of the methods and genotypes were performed based on the freezing tolerances of several different flower parts, including corolla, style, filament, ovary, and ovules.

\section{Materials and Methods} were estimated at over $\$ 2$ billion from the 2007 freezes (Warmund et al., 2008; Wisniewski et al., in press).

Most studies on cold-hardiness in northern highbush blueberry (Vaccinium corymbosum $\mathrm{L}$.) have focused on midwinter hardiness 
Blueberry and Cranberry Research Station, Chatsworth, NJ, to the USDA-ARS Appalachian Fruit Research Station, Kearneysville, $\mathrm{WV}$, for the experiment. After transfer in Nov. 2007, the dormant, 1.0-m tall plants were held in an unheated greenhouse to first satisfy their chilling requirements $(1000 \mathrm{~h}$ from 0 to $7^{\circ} \mathrm{C}$ ). Subsequently, plants were transferred to a heated greenhouse $\left(20{ }^{\circ} \mathrm{C}\right.$ day $/ 16$ to $17{ }^{\circ} \mathrm{C}$ night) until flower buds opened. When buds reached stages 5 to 6 (flowers distinctly separated and corollas expanding) according to the developmental scale described by Spiers (1978), flowers were exposed to freezing temperatures using two methods by 1) placing whole plants in a frost chamber available at the USDA-ARS, Kearneysville, WV, location and by 2) placing cut shoots from plants in a glycol freezing bath at the USDA-ARS, Beltsville, MD, location.

"Whole plant" freezing method. Plants with flowers at developmental stages 5 to 6 (Spiers, 1978) were placed in an insulated radiation frost chamber $(1.2 \mathrm{~m}$ wide $\times 2.4 \mathrm{~m}$ long $\times 2.1 \mathrm{~m}$ high) that was chilled by ethylene glycol coolant passing through $59 \mathrm{~m}$ of finned residential heating/cooling coils located $1.5 \mathrm{~m}$ above the chamber floor. The coolant temperature was controlled with a refrigerated recirculation bath (Model 1179MD; VWR, Radnor, PA). The chamber temperature was monitored with thermocouples placed at heights of 10,50 , and $100 \mathrm{~cm}$ in the center of the chamber. Thermocouples were also placed in four open flowers of the blueberry plants to monitor air temperature around the flower pistils. Each of the five cultivars was treated separately because flowering occurred over a range of days. The afternoon before treatment, plants of one cultivar were moved into the chamber; the temperature was gradually lowered to $1{ }^{\circ} \mathrm{C}$ and held overnight. Control plants were maintained at $4{ }^{\circ} \mathrm{C}$ in a separate cold room. At $0800 \mathrm{HR}$ the next day, the temperature in the chamber was lowered to $-10{ }^{\circ} \mathrm{C}$ at the rate of $1{ }^{\circ} \mathrm{C} \cdot \mathrm{h}^{-1}$. To induce ice nucleation, plants were misted with deionized water when the air temperature reached $0{ }^{\circ} \mathrm{C}$. Two plants (where each plant was considered a repetition) were removed at $1^{\circ}$ intervals in flower temperature from -2 to $-10{ }^{\circ} \mathrm{C}$ and transferred to a room maintained at $7{ }^{\circ} \mathrm{C}$ for $2 \mathrm{~h}$. Plants were then transferred to a greenhouse maintained at $15{ }^{\circ} \mathrm{C}$ for $24 \mathrm{~h}$ before evaluation of freeze damage to flowers.

"Excised shoot" freezing method. Approximately 25 shoots with open flowers at developmental stages 5 to 6 (Spiers, 1978) were randomly cut from the total number of potted plants of each cultivar in West Virginia (before freeze treatments were begun) and shipped overnight to Beltsville, MD. On arrival, 20 shoots were selected and placed in glass test tubes $(38 \times 200 \mathrm{~mm})$, one per tube, and exposed to gradually lowering temperatures in a glycol bath (Model 2325; Forma Scientific, Marietta, $\mathrm{OH}$ ) as previously described by Arora et al. (2000). Control shoots were held at $4{ }^{\circ} \mathrm{C}$. Two tubes were removed from the bath at $1{ }^{\circ} \mathrm{C}$ intervals in flower temperature from -2 to $-10{ }^{\circ} \mathrm{C}$ and then placed on ice overnight. The next day, tubes were transferred to a $4{ }^{\circ} \mathrm{C}$ cold room for $1 \mathrm{~h}$ and then incubated at room temperature for $24 \mathrm{~h}$ before evaluation of flowers.

Evaluation of freeze damage. After freezing, two shoots per genotype per temperature treatment with up to five flowers in five flower clusters (yielding up to 25 flowers per repetition depending on number of flower clusters present) at developmental stages 5 to 6 were assessed for freeze injury. Damage to six types of floral tissue (corolla, filament, style, exterior ovary, interior ovary, and ovule) was noted at both locations. For corolla, filament, and ovule tissues, damage was noted as not visible $(0 \%)$ or visibly damaged $(100 \%)$. In the case of the corolla, damage was apparent as either a water-soaked or necrotic appearance. The water-soaked appearance developed earlier, at higher subfreezing temperatures, followed by the development of necrosis at lower temperatures. Damage to all other tissues was based on the presence of necrotic tissue. Damage to style, exterior ovary, and interior ovary tissues was scored as not visible $(0 \%)$, partially necrotic $(50 \%)$, or completely $(100 \%)$ necrotic. At the Beltsville location, damage to stigma, anther, and placenta tissues was also evaluated and scored as $0 \%, 50 \%$, or $100 \%$.

Microscopy. Images of 'Bluecrop' floral tissues were captured at the time of scoring at the Beltsville location with the Zeiss Discovery.V12 stereo microscope and AxioCam HRc (AxioVision 4.8; Carl Zeiss, Jena, Germany). Whole flowers and the scored flower parts were photographed across the range of nine treatment temperatures $\left(-2\right.$ to $\left.-10^{\circ} \mathrm{C}\right)$ plus the control temperature $\left(4^{\circ} \mathrm{C}\right)$.

Statistical analyses. Each genotype was rated for flower damage by evaluating two stems (i.e., replicates), each with $\approx 25$ flowers in five flower clusters, for each of the 10 freezing temperatures. For each replicate, the relationship between tissue freeze damage scores and temperature was modeled with SAS PROC GLIMMIX (SAS Institute, Inc., Cary, NC) using a generalized linear model with Beta distribution and logit link (Gbur et al., 2012; Stroup, 2013). A single estimate of $\mathrm{LT}_{50}$ was obtained by setting the damage score at $50 \%$ and solving the beta regression model for temperature. To ensure the $\mathrm{LT}_{50}$ was accurate and representative of the true underlying (beta) distribution of flower freeze damage scores observed for each replicate, the $\approx 25$ flowers scored at each temperature were sampled with replacement (i.e., resampled) (Manly, 1997) to obtain a sample of 25 damage scores for each observed temperature. A beta regression was fit and solved to obtain an estimate of $\mathrm{LT}_{50}$ for each resampling (i.e., bootstrapped sampling) of the damage scores observed from each replicate. This bootstrap sampling procedure was applied 200 times to the observed data composing each replicate producing 200 estimates of $\mathrm{LT}_{50}$. The median of these 200 $\mathrm{LT}_{50}$ values was used to represent the true
$\mathrm{LT}_{50}$ for the replicate. Both a one-way and a two-way ANOVA was fit to the median 200 ( $\mathrm{LT}_{50}$ bootstrap estimates) for each replicate. In the one-way ANOVA, pairwise means comparisons were conducted among the combinations of method $\times$ genotype. In the twoway ANOVA, pairwise means comparisons were conducted among genotypes subjected to each freeze method and between methods for each genotype. All pairwise means comparisons used the Royen-Tukey-Kramer multiplicity adjustment (Westfall et al., 2011). Each ANOVA model estimated differently sized among-replicate within-genotype variance components. Level of significance $\alpha=$ 0.05 was used.

\section{Results}

The main goal of this project was to determine if there is genotypic variability in frost tolerance of open blueberry flowers that can be exploited for breeding highbush cultivars that are more tolerant to late winter/ early spring frosts. The frost tolerance of open flowers of five cultivars, Bluecrop, Elliott, Hannah's Choice, Murphy, and Weymouth, with germplasm compositions that are predominantly highbush, $V$. corymbosum (Table 1), was determined using the two controlled freezing methods described in the "Materials and Methods" ("whole plant" and "excised shoot" methods). Table 2 shows the calculated $\mathrm{LT}_{50}$ for each evaluated flower part from each genotype. As can be seen, the flower parts showed different sensitivities to freezing temperatures. The corolla, filament, anther, and style were the most sensitive, with a mean $\mathrm{LT}_{50}$ of $-2.8^{\circ} \mathrm{C}$ (range of -2.05 to $-3.30{ }^{\circ} \mathrm{C}$ ),$-4.32{ }^{\circ} \mathrm{C}$ (range of -3.47 to $\left.-5.09^{\circ} \mathrm{C}\right),-4.94^{\circ} \mathrm{C}$ (range of -4.23 to $-6.4^{\circ} \mathrm{C}$ ), and $-5.14{ }^{\circ} \mathrm{C}$ (range of -4.30 to $-5.54{ }^{\circ} \mathrm{C}$ ), respectively. Next were the exterior ovary, stigma, ovules, and interior ovary with a mean $\mathrm{LT}_{50}$ of $-5.20^{\circ} \mathrm{C}$ (range of -4.88 to $-5.79^{\circ} \mathrm{C}$ ), $-6.31^{\circ} \mathrm{C}$ (range of -5.40 to $\left.-8.13^{\circ} \mathrm{C}\right),-6.54{ }^{\circ} \mathrm{C}$ (range of -5.54 to $-7.78{ }^{\circ} \mathrm{C}$ ), and $-6.98{ }^{\circ} \mathrm{C}$ (range of -5.97 to $-8.31^{\circ} \mathrm{C}$ ), respectively. The placenta was most resistant to freezing with a mean $\mathrm{LT}_{50}$ of $-7.17{ }^{\circ} \mathrm{C}$ (range of -5.96 to $-8.49{ }^{\circ} \mathrm{C}$ ). Figure 1 shows damage to the corolla $\left(\mathrm{LT}_{50}=-2.45{ }^{\circ} \mathrm{C}\right)$, style $\left(\mathrm{LT}_{50}=\right.$ $-4.30{ }^{\circ} \mathrm{C}$ ), filament $\left(\mathrm{LT}_{50}=-4.24{ }^{\circ} \mathrm{C}\right)$, anthers $\left(\mathrm{LT}_{50}=-4.38{ }^{\circ} \mathrm{C}\right)$, exterior ovary $\left(\mathrm{LT}_{50}=\right.$ $\left.-4.93{ }^{\circ} \mathrm{C}\right)$, interior ovary $\left(\mathrm{LT}_{50}=-5.97{ }^{\circ} \mathrm{C}\right)$,

Table 1. Germplasm composition ${ }^{z}$ of genotypes evaluated for frost tolerance of open flowers.

\begin{tabular}{lcc}
\hline & \multicolumn{2}{c}{ Germplasm $(\%)^{\mathrm{y}}$} \\
\cline { 2 - 3 } Genotype & V. corymbosum & V. angustifolium \\
\hline Bluecrop & 93.6 & 6.4 \\
Elliott & 100 & - \\
Hannah's & $92.2^{\mathrm{y}}$ & 7.8 \\
$\quad$ Choice & & \\
Murphy & 93.6 & 6.4 \\
Weymouth & 87.5 & 12.5 \\
\hline
\end{tabular}

${ }^{\mathrm{z}}$ According to Clark et al., 1996; Ehlenfeldt, 1994; Hancock and Siefker, 1982.

${ }^{\mathrm{y}} \mathrm{A}$ total of $23.1 \%$ of this $92.2 \%$ would have formerly been considered $V$. atrococcum (Gray) 


\begin{tabular}{lcccccc}
\hline & \multicolumn{5}{c}{ LT $_{50}$ for each flower part $\left({ }^{\circ} \mathrm{C}\right)$} \\
\cline { 2 - 7 } Cultivar & Corolla & $\begin{array}{c}\text { Style/ } \\
\text { stigma }^{\mathrm{y}}\end{array}$ & $\begin{array}{c}\text { Filament/ } \\
\text { anthers }^{\mathrm{y}}\end{array}$ & $\begin{array}{c}\text { Exterior ovary/ } \\
\text { interior ovary }\end{array}$ & Ovules & Placenta $^{\mathrm{y}}$ \\
\hline Bluecrop & $-2.45 \mathrm{a}^{\mathrm{x}}$ & $-4.30 \mathrm{a} /-5.40 \mathrm{a}$ & $-4.24 \mathrm{a} /-4.38 \mathrm{a}$ & $-4.93 \mathrm{a} /-5.97 \mathrm{a}$ & $-5.94 \mathrm{a}$ & $-5.96 \mathrm{a}$ \\
Weymouth & $-2.05 \mathrm{a}$ & $-5.34 \mathrm{ab} /-8.13 \mathrm{a}$ & $-3.94 \mathrm{ab} /-4.38 \mathrm{ab}$ & $-4.88 \mathrm{ab} /-7.42 \mathrm{a}$ & $-7.78 \mathrm{a}$ & $-7.78 \mathrm{a}$ \\
Elliott & $-3.30 \mathrm{a}$ & $-5.24 \mathrm{~b} /-6.09 \mathrm{a}$ & $-3.47 \mathrm{a} /-4.23 \mathrm{ab}$ & $-5.24 \mathrm{ab} /-6.81 \mathrm{a}$ & $-6.18 \mathrm{a}$ & $-7.26 \mathrm{a}$ \\
Hannah's Choice & $-3.18 \mathrm{a}$ & $-5.29 \mathrm{~b} /-5.68 \mathrm{a}$ & $-4.86 \mathrm{ab} /-5.30 \mathrm{~b}$ & $-5.79 \mathrm{~b} /-8.31 \mathrm{a}$ & $-7.25 \mathrm{a}$ & $-8.49 \mathrm{a}$ \\
Murphy & $-3.10 \mathrm{a}$ & $-5.54 \mathrm{~b} /-6.23 \mathrm{a}$ & $-5.09 \mathrm{~b} /-6.40 \mathrm{~b}$ & $-5.14 \mathrm{ab} /-6.38 \mathrm{a}$ & $-5.54 \mathrm{a}$ & $-6.36 \mathrm{a}$ \\
\hline
\end{tabular}

zTwo controlled freezing methods were used; one was performed in Kearneysville, WV, in which whole plants were placed in a radiation frost chamber, and the other, carried out in Beltsville, MD, in which excised shoots were placed in a glycol-freezing bath. A two-way analysis of variance (method $\times$ genotype) found no significant method effect except in the case of exterior ovary damage. Genotype main effect is considered.

y The flower parts, stigma, anthers, and placenta, were analyzed only in Beltsville, where excised shoots were placed in a glycol-freezing bath. Therefore, for these flower parts, a one-way analysis of variance was performed to test for genotype effects.

${ }^{\mathrm{x}}$ Means with different letters are considered significantly different $(\alpha=0.05)$ according to the RoyenTukey-Kramer test.
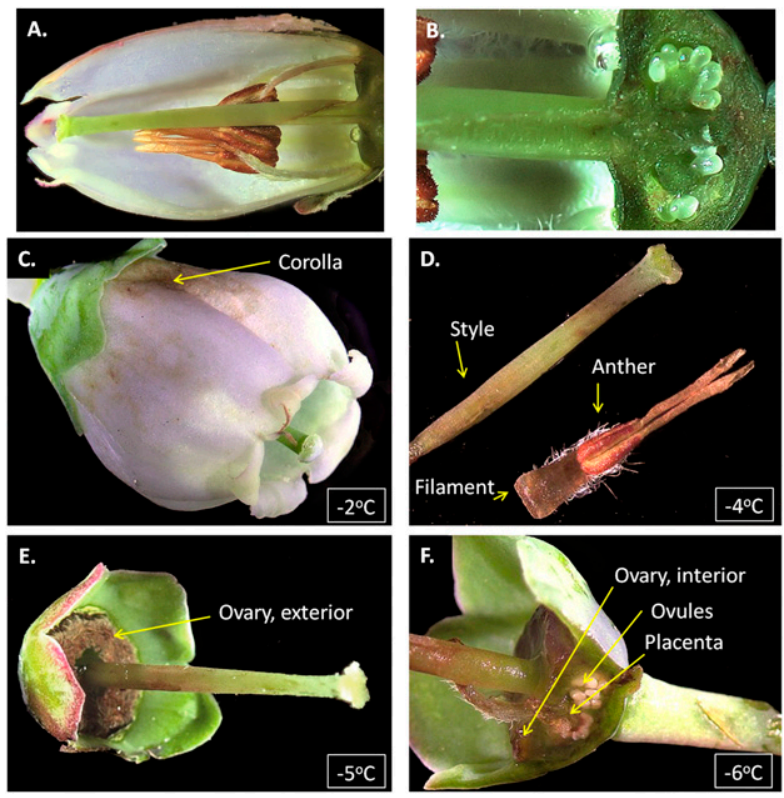

Fig. 1. 'Bluecrop' images showing control and damaged floral tissues. (A-B) Sections of control flowers $\left(4{ }^{\circ} \mathrm{C} /\right.$ no freeze treatment) showing undamaged flower parts. $(\mathbf{C}-\mathbf{F})$ Sections of flowers from the "excised shoot" freezing method showing various damaged floral tissues at temperatures near the $\mathrm{LT}_{50}$ for each of those tissues: $(\mathbf{C})$ corolla $\left(\mathrm{LT}_{50}=-2.45^{\circ} \mathrm{C}\right) ;(\mathbf{D})$ style $\left(\mathrm{LT}_{50}=-4.30^{\circ} \mathrm{C}\right)$, filament $\left(\mathrm{LT}_{50}=-4.24{ }^{\circ} \mathrm{C}\right)$, and anther $\left(\mathrm{LT}_{50}=4.38^{\circ} \mathrm{C}\right) ;(\mathbf{E})$ exterior ovary $\left(\mathrm{LT}_{50}=-4.93^{\circ} \mathrm{C}\right)$; and $(\mathbf{F})$ interior ovary $\left(\mathrm{LT}_{50}=-5.97^{\circ} \mathrm{C}\right)$, ovules $\left(\mathrm{LT}_{50}=-5.94{ }^{\circ} \mathrm{C}\right)$, and placenta $\left(\mathrm{LT}_{50}=-5.96{ }^{\circ} \mathrm{C}\right) . \mathrm{LT}_{50}=$ lethal temperature ${ }_{50}$.

ovules $\left(\mathrm{LT}_{50}=-5.94^{\circ} \mathrm{C}\right)$, and placenta $\left(\mathrm{LT}_{50}=\right.$ $\left.-5.96^{\circ} \mathrm{C}\right)$ of 'Bluecrop' at various temperatures near the $\mathrm{LT}_{50}$ for each of those tissues.

A two-way ANOVA analysis (among genotypes for each freeze method and between methods for each genotype) found no significant effect of the freezing method ("whole plants" in frost chambers vs. "excised shoots" in freezing glycol bath) on the calculated freeze damage to the various flower parts except in the case of exterior ovary damage (data not shown). The mean $\mathrm{LT}_{50}$ for exterior ovary damage was $-4.83{ }^{\circ} \mathrm{C}$ for the "excised shoot" method and slightly lower at $-5.56^{\circ} \mathrm{C}$ for the "whole plant" method. A significant genotype main effect was found on freeze damage to the style, filament, anthers, and exterior ovary (Table 2). For the style, 'Bluecrop' was the most sensitive to freezing with an $\mathrm{LT}_{50}$ of $-4.30^{\circ} \mathrm{C}$, whereas 'Murphy' was the most resistant with an $\mathrm{LT}_{50}$ of $-5.54{ }^{\circ} \mathrm{C}$. 'Bluecrop' was significantly less tolerant to freezing than 'Murphy', 'Elliott', and 'Hannah's Choice'. Regarding the filament and anthers, 'Elliott' was the most freezing-sensitive $\left(\mathrm{LT}_{50}\right.$ of $-3.47{ }^{\circ} \mathrm{C}$ for the filament and $-4.23{ }^{\circ} \mathrm{C}$ for the anthers), whereas 'Murphy' was the least sensitive $\left(\mathrm{LT}_{50}\right.$ of $-5.09{ }^{\circ} \mathrm{C}$ for the filament and $-6.40{ }^{\circ} \mathrm{C}$ for the anthers). For the filament, 'Murphy' was significantly more tolerant to freezing than 'Elliott' and 'Bluecrop'. For the anthers, 'Bluecrop' was significantly less tolerant to freezing than 'Hannah's Choice' and 'Murphy'. Finally, regarding the exterior ovary tissue, 'Hannah's Choice' was significantly more freezingtolerant than 'Bluecrop'.
Unseasonably warm winters and springs can induce premature growth and development of floral and vegetative buds. If these unusually warm periods are followed by a late winter or early spring frost, damage to vulnerable plant tissues and organs can occur, resulting in devastating crop losses. One way to reduce fruit losses, from late winter or early spring frosts, would be to breed varieties with increased frost tolerance of open flowers if variation in this trait actually exists.

In a study comparing frost tolerance of open flowers of five rabbiteye blueberry cultivars, 'Southland' was found to be significantly more frost-tolerant than the other four cultivars (Gupton, 1983). Although $\mathrm{LT}_{50} \mathrm{~S}$ were not calculated in the study, percent damaged corollas and percent of flowers that fruited were determined for flowers after a natural frost event in March resulted in exposure to $-2{ }^{\circ} \mathrm{C}$. Although 'Southland' had the largest number of buds at stage 6 of development of all the cultivars tested when the frost occurred, it also had significantly higher percentage of flowers that later fruited. The percentage of stage 6 flowers with damaged corollas (22\%) in 'Southland' was approximately equal to the percentage of flowers that failed to set fruit $(23 \%)$. Furthermore, percentage fruit set was approximately the same when compared between hand-pollinated and open-pollinated frost-damaged flowers. Therefore, Gupton (1983) concluded that reduction in fruit set was probably not the result of lack of pollination of flowers with damaged corollas by pollinators but likely the result of damage of another flower part, the pistils, which must have occurred at $-2{ }^{\circ} \mathrm{C}$. In another study on rabbiteye blueberry, NeSmith et al. (1999) found that fruit set resulting from open pollination of cultivars, Tifblue and Brightwell, declined sharply after exposure to temperatures as high as $-1{ }^{\circ} \mathrm{C}$ for $1 \mathrm{~h}$ although damage to flower parts was not always visible. Only one cultivar, Tifblue, was used in both the Gupton (1983) and NeSmith et al. (1999) studies, and fruit set after bee pollination and hand pollination was not compared in NeSmith et al. (1999). 'Tifblue' was one of the most frost-sensitive cultivars in the Gupton (1983) study, however; thus damage to pistils of 'Tifblue' may have occurred at temperatures as high as -1 to $-2{ }^{\circ} \mathrm{C}$.

Patten et al. (1991) compared freeze injury of flower buds and flowers of several rabbiteye, southern highbush, and northern highbush varieties in the field after freezes in March and April of 1988 and 1989. In general, rabbiteye had more frost damage than southern highbush, which had more frost damage than northern highbush blueberry at similar stages of flower bud development (stages 4 to 6). Hancock et al. (1987) assessed flower bud injury in 18 cultivars of highbush blueberry after spring frosts in April and May of 1983 and 1986. Significant variation in bud damage was observed among cultivars. 
However, unlike in our study, the average stage of bud development was only 2.36 in 1983 and 4.69 in 1986 at the time of the freezes.

In our study with five highbush blueberry cultivars, controlled freezes were performed using two methods by placing whole plants in a frost chamber and detached shoots in a glycol-freezing bath rather than evaluating damage after natural freezes in the field. Because freezes were controlled, our studies focused on evaluating flowers at later stages of development, stages 5 to 6 , when flowers are more susceptible to frost damage. These methods enabled the calculation of $\mathrm{LT}_{50}$ for all major flower parts. First, there was no significant effect of the freezing method on the calculated freeze damage to the various flower parts, except for a small difference, less than $1^{\circ}$, in the $\mathrm{LT}_{50}$ of the exterior of the ovary. Although it is possible the exterior of the ovary is slightly more vulnerable to damage in excised shoots as compared with whole plants, the small difference in $\mathrm{LT}_{50}$ might instead be the result of variability introduced by having different evaluators of the tissue damage at the two locations. That there was nearly no difference overall in the calculated $\mathrm{LT}_{50}$ values using the two methods is a very important finding. Freezing baths or freezers are more readily available to researchers than frost chambers, and this study suggests that the detached shoot/ freezing bath method should give results as similar to a natural freeze event in the field as would the whole plant/frost chamber method.

Second, the various flower parts of the highbush blueberry were markedly different in terms of their susceptibility to freeze damage. Of the flower parts evaluated, the corolla was the most susceptible followed by the filament, anther, style, exterior ovary, stigma, ovules, interior ovary, and placenta. The overall average $\mathrm{LT}_{50}$ values of the interior ovary and placenta were very similar as were the average $\mathrm{LT}_{50}$ values of the anther, style, and exterior ovary. The female flower parts most sensitive to frost (i.e., would affect fruit yield if damaged) were the style and exterior ovary. Damage to the corolla might also affect fruit yield if pollinator activity were decreased. In this study, we did not attempt to pollinate the flowers after freeze treatments, but it would be worth further investigation to determine the extent of corolla damage that affects pollinator activity. In the study of Gupton (1983), in which a natural freeze of $-2{ }^{\circ} \mathrm{C}$ occurred, it was concluded that damaged corollas were not responsible for the reduction in fruit yield, whereas lack of fertilization resulting from damaged pistils probably was.
Third, relatively small but significant differences among genotypes were observed in $\mathrm{LT}_{50}$ of the style, filament, anther, and exterior ovary (Table 2). Minus the corolla, these were the flower parts that were most sensitive to freeze damage. Regarding the female flower parts, styles of 'Elliott', 'Hannah's Choice', and 'Murphy' as well as exterior ovaries of 'Hannah's Choice' were significantly more frost-tolerant than those of 'Bluecrop'. Regarding the male flower parts, filaments of 'Murphy' were significantly more frost-tolerant than 'Bluecrop' and 'Elliott', and anthers of 'Murphy' and 'Hannah's Choice' were more tolerant than those of 'Bluecrop'. In general, 'Hannah's Choice' and 'Murphy' were the most frost-tolerant, whereas 'Bluecrop' was the least tolerant. 'Weymouth', which had the highest percentage of the cold-hardy lowbush species ( $V$. angustifolium Aiton) in its pedigree (Table 1), was not more frost-tolerant than the other cultivars. In conclusion, we did find genotypic variability in frost tolerance of open highbush blueberry flowers. These results suggest that evaluation of more genotypes to identify sources of still greater frost tolerance among the Vaccinium species is warranted.

\section{Literature Cited}

Arora, R., L.J. Rowland, J.S. Lehman, C.C. Lim, G.R. Panta, and N. Vorsa. 2000. Genetic analysis of freezing tolerance in blueberry (Vaccinium section Cyanococcus). Theor. Appl. Genet. 100:690-696.

Arora, R., L.J. Rowland, E.L. Ogden, A.L. Dhanaraj, C.O. Marian, M.K. Ehlenfeldt, and B. Vinyard. 2004. Dehardening kinetics, bud development, and dehydrin metabolism in blueberry cultivars during deacclimation at constant, warm temperatures. J. Amer. Soc. Hort. Sci. 129:667-674.

Bittenbender, B.C. and G.S. Howell. 1976. Cold hardiness of flower buds from selected highbush blueberry cultivars (Vaccinium australe Small). J. Amer. Soc. Hort. Sci. 101:135-139.

Clark, J.R., J.N. Moore, and A.D. Draper. 1996 'Ozarkblue' southern highbush blueberry. HortScience 31:1043-1045.

Ehlenfeldt, M.K. 1994. The genetic composition and tetrasomic inbreeding coefficients of highbush blueberry cultivars. HortScience 29:1342-1345.

Ehlenfeldt, M.K., L.J. Rowland, E.L. Ogden, and B. Vinyard. 2007. Bud cold hardiness of Vaccinium ashei, V. constablaei, and hybrid derivatives and their potential for producing northern-adapted rabbiteye cultivars. HortScience 42:1131-1134.

Ehlenfeldt, M.K., L.J. Rowland, E.L. Ogden, and B. Vinyard. 2012. Cold hardiness, acclimation, and deacclimation among diverse blueberry (Vaccinium spp.) genotypes. J. Amer. Soc. Hort. Sci. 137:31-37.

Gbur, E.E., W.W. Stroup, K.S. McCarter, S Durham, L.J. Young, M. Christman, M. West, and M. Kramer. 2012. Analysis of generalized linear mixed models in the agricultural and natural resources sciences. American Society of Agronomy, Soil Science Society of America, and Crop Science Society of America, Madison, WI.

Gu, L., P.J. Hanson, W.M. Post, D.P. Kaiser, B. Yang, R. Nemani, S.G. Pallardy, and T. Meyers. 2008. The 2007 eastern US spring freeze: Increased cold damage in a warming world? Bioscience 58:253-262.

Gupton, C.L. 1983. Variability among rabbiteye blueberry cultivars for tolerance of flowers to frost. HortScience 18:713-714.

Hancock, J.F., J.W. Nelson, H.C. Bittenbender, P.W. Callow, J.S. Cameron, S.L. Krebs, M.P. Pritts, and C.M. Schumann. 1987. Variation among highbush blueberry cultivars in susceptibility to spring frost. J. Amer. Soc. Hort. Sci. 112:702-706.

Hancock, J.F. and J.H. Siefker. 1982. Levels of inbreeding in highbush blueberry cultivars. HortScience 17:363-366.

Manly, B.F.J. 1997. Randomization, bootstrap and Monte Carlo methods in biology. 2nd Ed. Chapman \& Hall, London, UK.

Modlibowska, I. 1975. Induction of parthenocarpic apples of Bramley's seedling by low concentrations of gibberellins. J. Hort. Sci. 50: 21-22.

NeSmith, D.S., G. Krewer, and O.M. Lindstrom. 1999. Fruit set of rabbiteye blueberry (Vaccinium ashei) after subfreezing temperatures. J. Amer. Soc. Hort. Sci. 124:337-340.

Patten, K., E. Neuendorff, G. Nimr, J.R. Clark, and G. Fernandez. 1991. Cold injury of southern blueberries as a function of germplasm and season of flower bud development. HortScience 26:18-20.

Rowland, L.J., E.L. Ogden, M.K. Ehlenfeldt, and R. Arora. 2008. Cold tolerance of blueberry genotypes throughout the dormant period from acclimation to deacclimation. HortScience 43: 1970-1974.

Rowland, L.J., E.L. Ogden, M.K. Ehlenfeldt, and B. Vinyard. 2005. Cold hardiness, deacclimation kinetics, and bud development among 12 diverse blueberry genotypes under field conditions. J. Amer. Soc. Hort. Sci. 130:508-514.

Spiers, J.M. 1978. Effect of stage of bud development on cold injury in rabbiteye blueberry. J. Amer. Soc. Hort. Sci. 103:452-455.

Stroup, W.W. 2013. Generalized linear mixed models-Modern concepts, methods and applications. CRC Press/Taylor \& Francis Group, Boca Raton, FL.

Warmund, M.R., P. Guinan, and G. Fernandez. 2008. Temperatures and cold damage to small fruit crops across the eastern United States associated with the April 2007 freeze. HortScience 43:1643-1647.

Westfall, P.H., R.D. Tobias, and R.D. Wolfinger 2011. Multiple comparisons and multiple tests using $\mathrm{SAS}^{\circledR}$. 2nd Ed. SAS Institute Inc., Cary, NC

Wisniewski, M., A. Nassuth, C. Teulières, C. Marque, J. Rowland, P.B. Cao, and A. Brown. Genomics of cold hardiness in woody plants. Crit. Rev. Plant Sci. (in press). 